\title{
THE EFFECT OF THERMAL INSULATION OF AN APARTMENT BUILDING ON THE THERMO-HYDRAULIC STABILITY OF ITS HEATING SYSTEM
}

\author{
Mária KURČOVÁ ${ }^{*}$
}

\section{Abstract}

The contribution aims to investigate the effect of the decreased thermal losses of an apartment building due to the thermal insulation of opaque external building constructions and the replacement of transparent constructions. It emphasizes the effect of the thermal characteristics of external constructions on the functionality of the existing heating system in the building and the related requirements for the renovation of the heating system in order to ensure the hydraulic stability of the system and the thermal comfort of the inhabitants.

\section{Address}

1 Department of Building Services, Slovak University of Technology in Bratislava, Faculty of Civil Engineering, Bratislava, Slovakia

* Corresponding author: maria.kurcova@stuba.sk

\section{Key words}

- Thermal insulation,

- hydraulic stability,

- heating system,

- valves.

\section{INTRODUCTION}

The construction of apartment buildings in Slovakia started expanding in 1950. The best technologies and procedures available were used in the construction process at that time. External constructions were being made from materials with thermal characteristics corresponding to the regulations and standards valid at the time of their construction.

Currently, the STN 730540 standard has been valid since 1 January 2013. There are four values of thermal resistance given in the standard: the minimum, normalized, recommended and target (STN 73 0540-2, 2012).

The requirements for the minimum level of the thermal insulation of building constructions, in terms of their heat transfer coefficient (U-value), has become stricter compared to the values that were valid in 1964 and 1977. For refurbished buildings the requirements are 50 to $70 \%$ stricter for external walls, 40 to $60 \%$ stricter for the roof, and 50 to $60 \%$ stricter for windows (Chmúrny, 2003; STN 73 0540, 1964; STN 73 0540-2 , 2012). This implies an energy-saving potential after refurbishment of 50 to $60 \%$.

\section{OBJECTIVE AND METHODOLOGY OF THE ANALYSIS}

The main objective is to analyse the effect of the thermal insulation of an apartment building's envelope on the heat loss and, subsequently, the effect of the change in the heat loss on the hydraulic balance of the heating system from the point of view of thermo-hydraulic stability. Based on this analysis, the convenience of different types of control valves applied to the existing heating systems in buildings after their renovation is to be determined from the point of view of their functioning and construction parameters.

The method is based on a parametrical study of the effect of changes in the thermal characteristics of a building envelope on thermal heat loss and the effect of the volume flow rate of the heating medium on pressure conditions in the heating system and on hydraulic stability, by a mathematical calculation tool created using Microsoft Excel ${ }^{\mathbb{R}}$.

A mathematical model of thermo-hydraulic stability was created to apply to the apartment buildings investigated (Fig. 1).

The following applies to the mathematical model (Bašta, 2003; Pekarovič at al., 1994; Roos, 2002): 
- for each node of the heating system, a so called "node rule" applies, which expresses the balance of the flows from one node to another,

- for each radiator circuit, a so called "circuit rule" applies, which expresses the balance of pressures causing the circulation of the heating medium, i.e., the balance of active and passive pressure gradients (pressure losses),

- for each radiator and heated space, the balance of proportional heat flows supplied by the heating medium to the radiator, the proportional flows emitted into the heated space by the radiator, and the proportional heat losses of the heated space, applies.

The buildings investigated in this experimental study were two eight-story buildings with unheated underground floors, located next to each other in Bratislava. The apartment building referred to as the "original" has its building construction in its original condition. The apartment building referred to as "refurbished" has the external walls, roof and ceiling of the underground floor insulated and the old windows replaced by new ones. The thermal characteristics of both buildings are listed in Tab. 1.
Tab. 1 Thermal characteristics of the envelope constructions of the two apartment buildings.

\begin{tabular}{|l|c|c|}
\hline \multirow{2}{*}{ Construction } & \multicolumn{2}{|c|}{$\begin{array}{c}\text { Heat transfer coefficient U } \\
\left(\mathbf{W} /\left(\mathbf{m}^{2} . \mathbf{K}\right)\right)\end{array}$} \\
\cline { 2 - 3 } & Original house & $\begin{array}{c}\text { Refurbished } \\
\text { house }\end{array}$ \\
\hline External walls & 1.09 & 0.28 \\
\hline Roof & 0.83 & 0.17 \\
\hline Ceiling of the underground story & 2.83 & 0.75 \\
\hline Transparent constructions & 2.7 & 1.2 \\
\hline
\end{tabular}

In both buildings the heating system has two pipes and a Tichelmann bottom uniflow distribution. The heating system is directly connected to the district heating. In the original house high-resistance valves are installed before each radiator and set on a low pressure loss. There is a combination of a pressure difference

\section{for the radiator and the} heated room

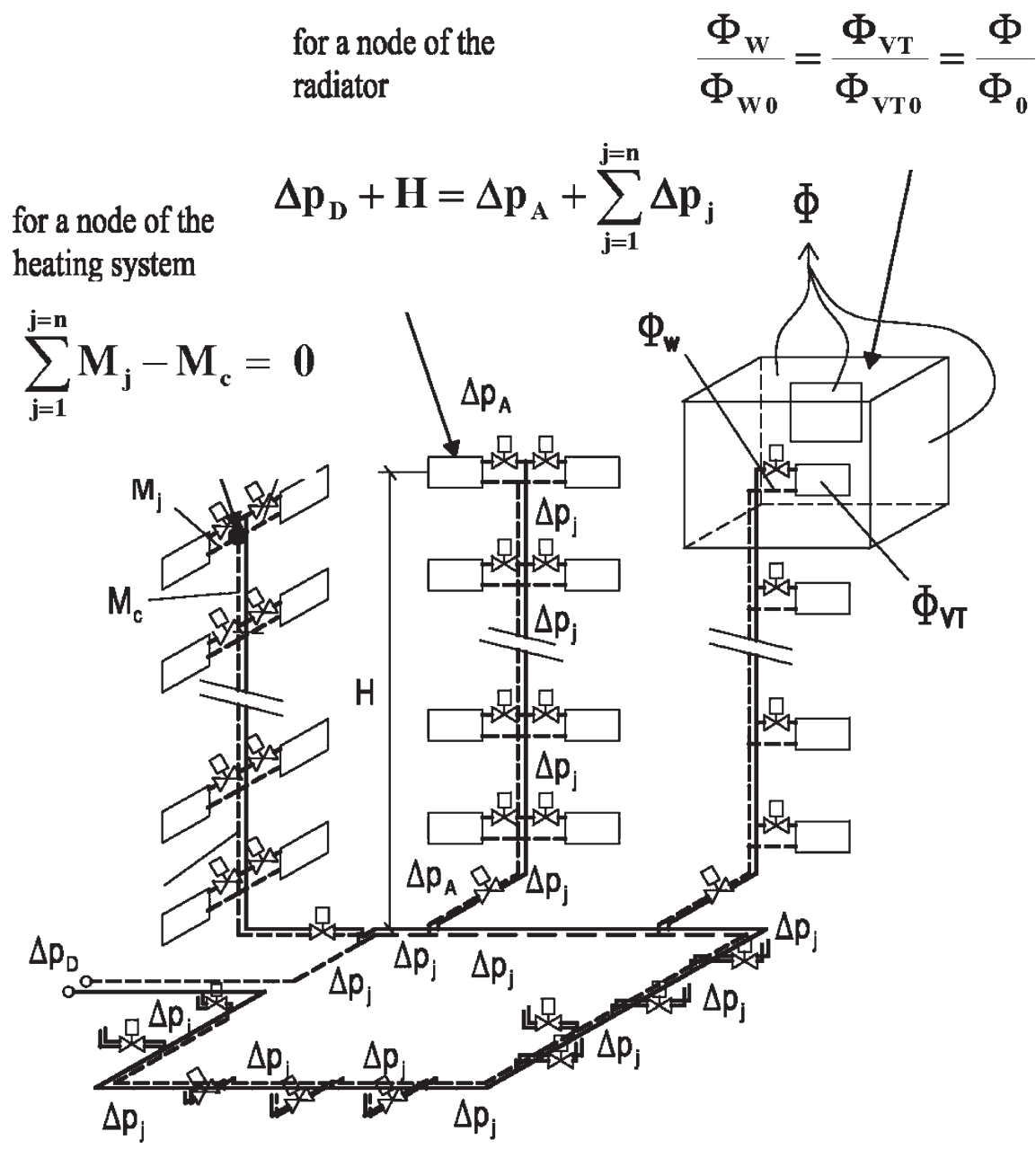

Fig. 1 Mathematical and physical model of thermo-hydraulic stability for an apartment building.

Description: $M_{j}$-volume flow to a node $(\mathrm{kg} / \mathrm{s}), M_{c}$-volume flow from a node $(\mathrm{kg} / \mathrm{s}), \Delta p_{D}$-pressure difference at the connection to the heating system (Pa), $H$-effective uplift (Pa), $\Delta p_{A}$ - pressure loss of the valves (Pa), $\Delta p_{j}$ - pressure loss of a section of the distribution network $(P a), \Phi_{W}$-immediate thermal flow of the radiator $(W), \Phi_{V T}$-immediate thermal output of the radiator $(W), \Phi-i m m e d i a t e$ thermal loss of the room $(W), \Phi_{W 0}$-calculation of heat flow supplied to the radiator $(W), \Phi_{V T O}$-calculation of thermal output of the radiator $(W), \Phi_{0}$-calculation of heat loss of the room $(W)$. 


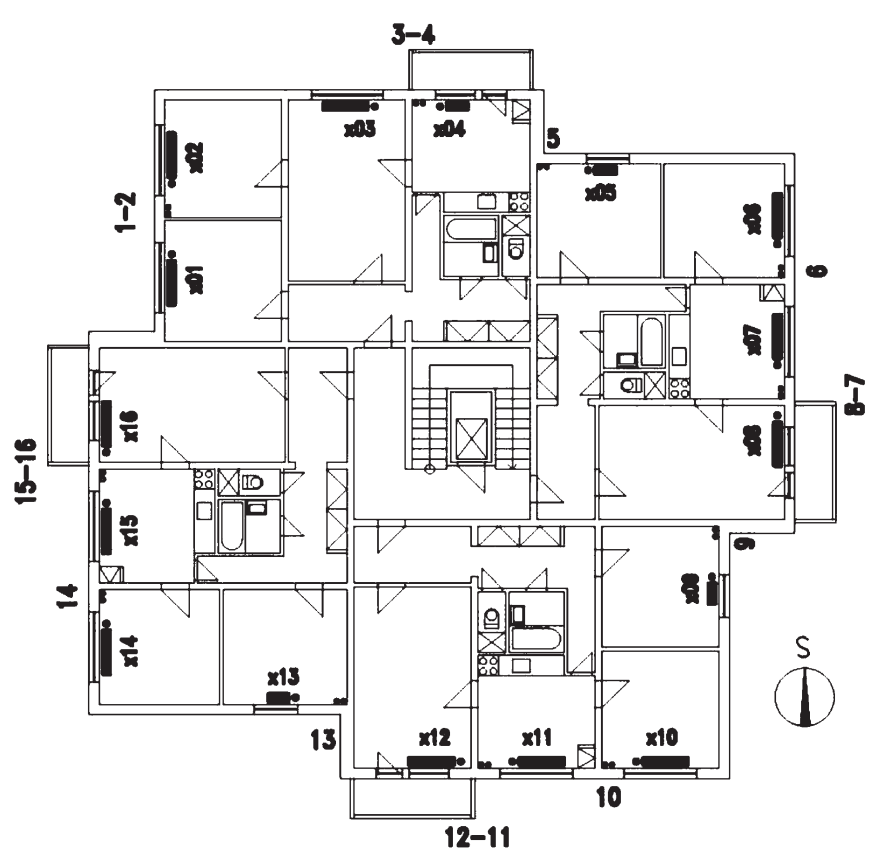

Fig. 2 Plan of a typical floor.

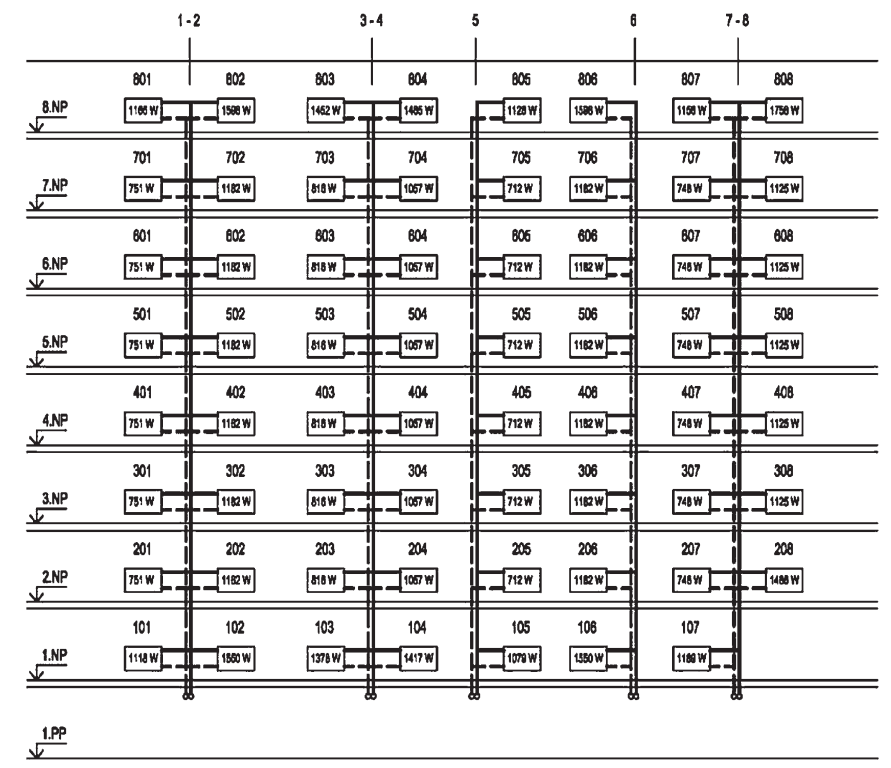

Fig. 4 Part of the unrolled scheme - the risers.

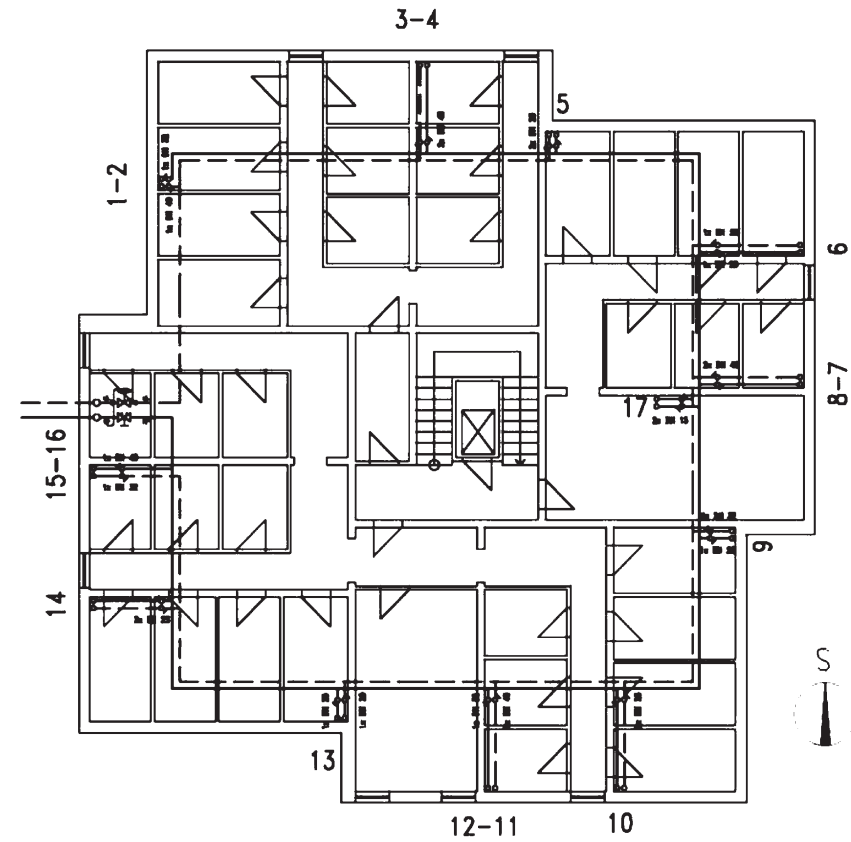

Fig. 3 Plan of the underground story with horizontal distribution pipes.

controller with a balancing valve on each riser. Stop valves are installed at the connection to the heating system (the connection to the heating system is the point where the primary network enters the building and becomes the heating system in the building). In the refurbished apartment building, there are also high-resistance valves installed before each radiator and set on a high pressure loss. There are spherical valves on each riser, and there is a combination of a pressure difference controller and a balancing valve at the connection to the heating system. Both heating systems have a hydraulic balance.

\section{THE EFFECT OF REFURBISHMENT ON THERMAL LOSSES}

After the refurbishment of the envelope constructions, the thermal characteristics of the refurbished building changed, as seen in Tab. 2. Tabs. 2 and 3 show the results of the calculations for the whole building and for a reference (typical) room in accordance with STN EN 12831 for the original house and for the refurbished house, respectively (Dahlsveen and Petráš, 2003; STN EN 12 831, 2004). The refurbishment of the envelope constructions is given for two variants: for a typical refurbishment (insulation of the external walls and replacement of the windows), and for a complex refurbishment (insula-

Tab. 2 Thermal heat loss of the building and of a typical room on the top, middle and bottom floors.

\begin{tabular}{|l|c|c|c|c|}
\hline \multirow{2}{*}{\multicolumn{1}{c|}{ Condition of the construction }} & \multicolumn{3}{c|}{ Thermal heat loss (W) } \\
\cline { 2 - 5 } & $\begin{array}{c}\text { Whole } \\
\text { building }\end{array}$ & \multicolumn{3}{|c|}{ Room - floor } \\
\cline { 2 - 5 } top & 133,458 & 1,452 & 816 & 1,378 \\
\hline Original & 65,203 & 1,016 & 381 & 942 \\
\hline Insulation of external walls and replacement of windows & 55,844 & 565 & 381 & 542 \\
\hline $\begin{array}{l}\text { Insulation of external walls, roof, ceiling of the underground floor and } \\
\text { replacement of windows }\end{array}$ & & & 3816 \\
\hline
\end{tabular}


Tab. 3 Changes in the thermal heat loss of the building and a typical room on the top, middle and bottom floors.

\begin{tabular}{|c|c|c|c|c|}
\hline \multirow{3}{*}{ Condition of the construction } & \multicolumn{4}{|c|}{ Change in heat loss $(\%)$} \\
\hline & \multirow{2}{*}{$\begin{array}{c}\text { Whole } \\
\text { building }\end{array}$} & \multicolumn{3}{|c|}{ Room - floor } \\
\hline & & top & middle & bottom \\
\hline Original & 100 & 100 & 100 & 100 \\
\hline Insulation of external walls and replacement of windows & 49 & 70 & 47 & 68 \\
\hline $\begin{array}{l}\text { Insulation of external walls, roof, ceiling of the underground floor } \\
\text { and replacement of windows }\end{array}$ & 42 & 39 & 47 & 39 \\
\hline
\end{tabular}

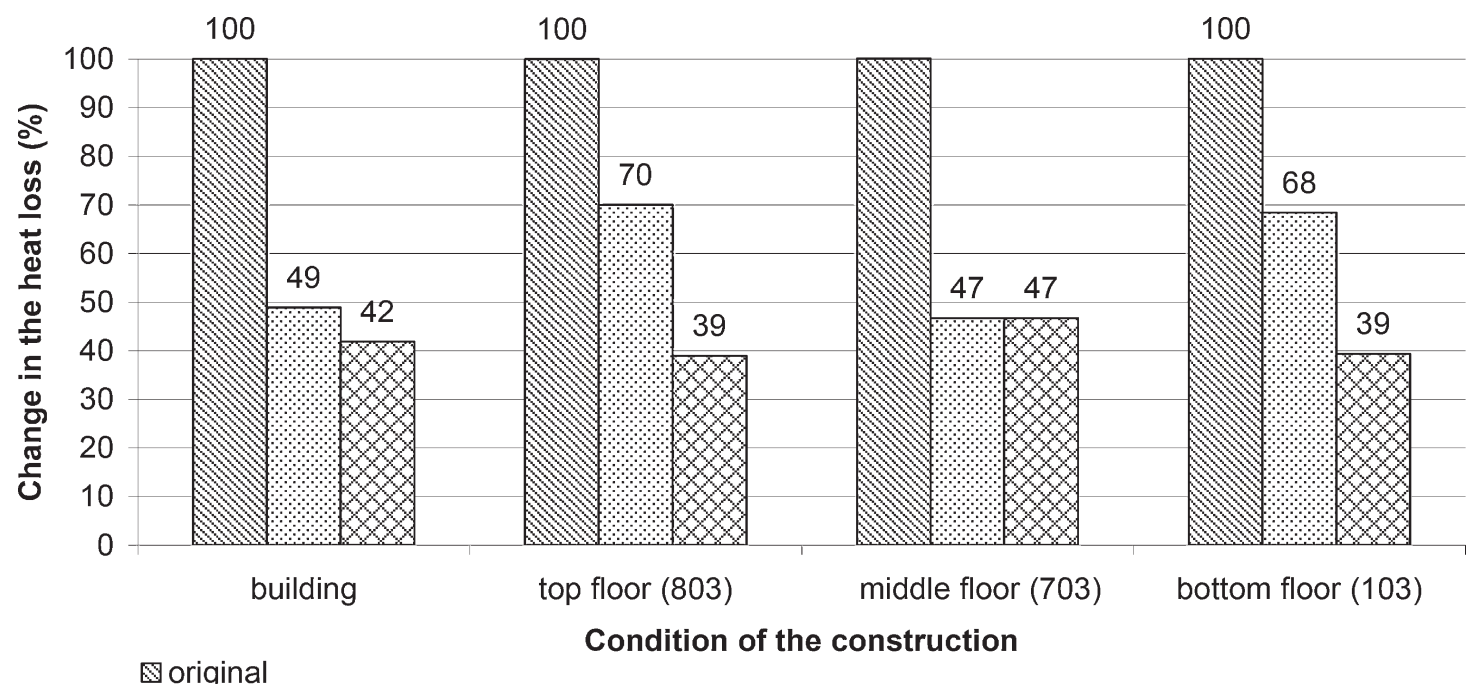

insulation of external walls + windows replacement

Q insulation of external walls + roof + ceiling of the underground floor + windows replacement

Fig. 5 Changes in the building heat losses and the reference room on the top, middle and lowest floors.

tion of the external walls, replacement of the windows, insulation of the roof, and insulation of the underground story).

From Tabs. 2 and 3 and the graph in Fig. 5, it can be seen that after the implementation of the energy-saving measures, the changes in the thermal losses of the rooms located on typical floors are of the same magnitude as those for the whole building. After the insulation of the external walls and replacement of any transparent constructions, the thermal losses decrease by about $50 \%$. However, the thermal losses of the rooms located on the top and bottom floors only decrease by about $30 \%$. After the additional thermal insulation of the roof and the ceiling of the underground floor, the thermal losses of the top and the bottom floors also decrease by $60 \%$. Thus, the rooms located in the middle of the building, the rooms located at the top and at the bottom, and also the building as a whole, have the same decrease in thermal losses after the complex thermal insulation.

From a comparison of the effect of the respective energy-saving measures applied to the envelope, it can be seen that it is not correct to base any calculation of the heat loss decreases only on the heat loss calculated for the whole building, but it is also important to check the heat loss of each room, which can differ significantly, depending on its location in the building. The most frequently applied energy-saving measures, i.e., the insulation of external walls and the replacement of old windows, decrease the heat loss on the middle floor to $50 \%$; however, on marginal floors the decrease can be up to $70 \%$. Taking this into consideration, it can be either assumed that the heat loss was only $70 \%$ on each floor or that the heat loss decreased to $50 \%$ and that the radiators on the top and the bottom floors should be replaced. However, these two approaches do not result in any savings. Therefore, in the refurbishment process it is also necessary to insulate the roof as well as the ceiling of the underground floor in order to make the decrease in heat losses uniform throughout the building, which is important in the process of the design and correction of the heating system. Otherwise, the heat loss of the rooms located on the marginal floors may not be fully covered by the heat output of the radiators.

\section{THE EFFECT OF REFURBISHMENT ON THE PRESSURE CONDITIONS IN A HEATING SYSTEM}

Taking into account the fact that the heating system is directly connected to the district heating, it is not possible to decrease the heat flow transferred by the heating system by decreasing the temperature gradient of the heating system. Such a measure would require a high amount of investment for the installation of a three-way mixing valve and an additional pressure source (a circulation pump), which would in turn result in increased operating costs. Therefore, it is suggested that the adjustment of the transferred heat flow to the actual heat loss of the building could be realized by changing the volume flow rate of the heating medium proportionally in to proportion defined in the previous section, i.e., $70 \%$ or $50 \%$.

The setting of the thermal losses to the changes in the temperature of the outside air is performed on the heat source, by means of an equithermic curve, thereby changing the temperature of the heating medium (Burkhardt and Kraus, 2006; Pekarovič at al., 1994). 


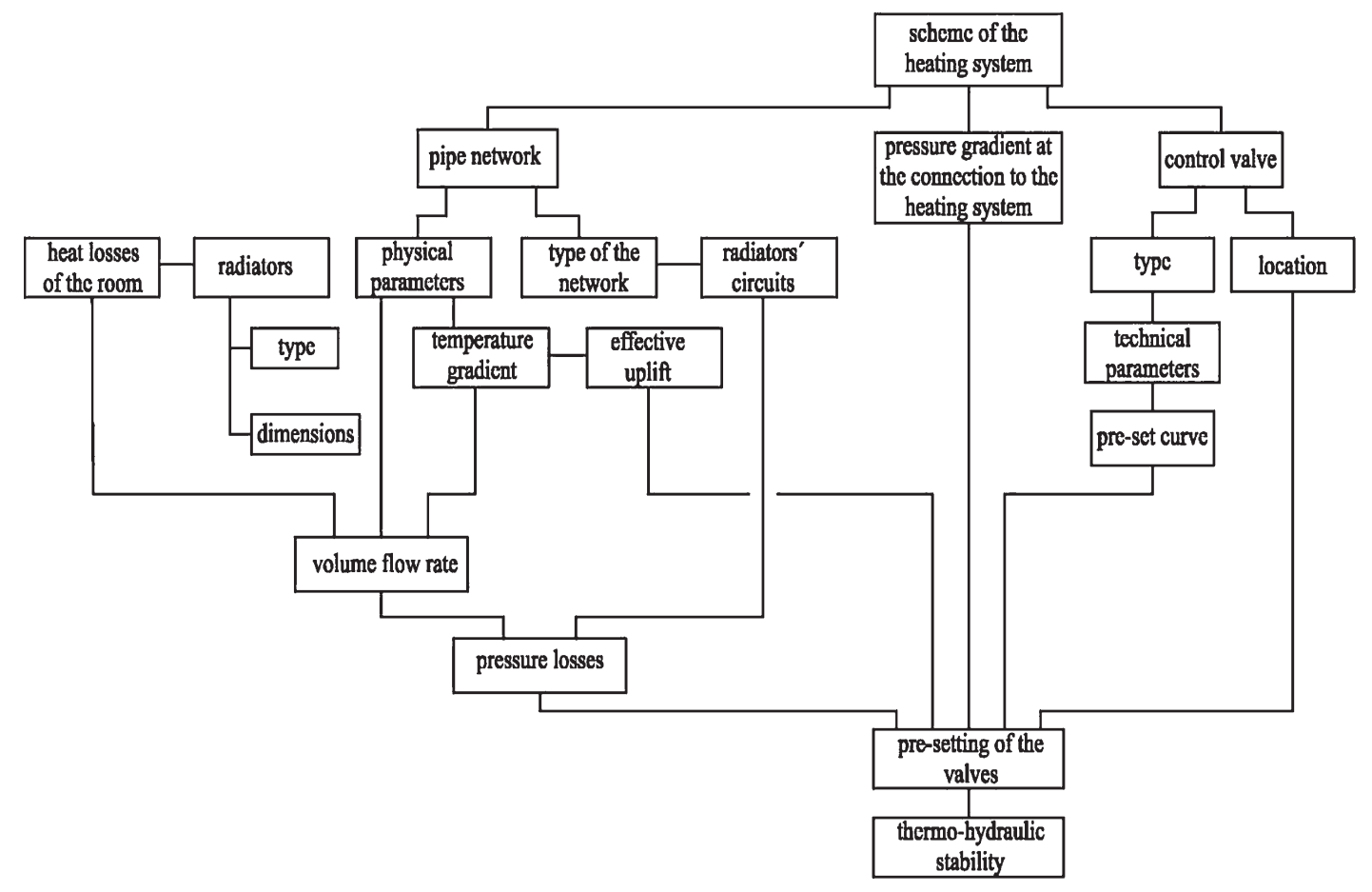

Fig. 6 Algorithm of the calculation of the thermo-hydraulic stability of the heating system.

The thermo-hydraulic stability of the heating system is affected by:

- the temperature of the heating medium by means of the effective uplift,

- the volume flow rate of the heating medium by means of pressure losses.

In the process of refurbishment, the system has to be designed so that any changes in the abovementioned parameters affect the thermo-hydraulic stability as little as possible. Since the distribution system remains the same and the effective uplift in the heating system is given by the construction height of the building, the only means of assuring the thermo-hydraulic stability is regulation valves.

Setting the pressure conditions and thereby the thermo-hydraulic stability of the heating system is based on the algorithm shown in Fig. 6 . The calculation of the pressure conditions was performed for the heating system on the top floor (indicated as 803 in Fig. 4), based on relationships thoroughly described in the literature (Burkhardt and
Kraus, 2006; Pekarovič at al., 1994; Dahlsveen and Petráš, 2003).

The values of the effective uplift, which were obtained from the equithermic curve for the temperature gradient of the heating medium of $90 / 70{ }^{\circ} \mathrm{C}$ and for the indoor air temperature of $20{ }^{\circ} \mathrm{C}$ (Šulcová, 1999), are given in Tab. 4. In the calculations, the effective uplift ratio of $u=0.5$ (the value commonly used by designers) and of $u=1.0$ (the actual effective uplift in the heating system) was assumed.

The pressure conditions occurring in the heating system were calculated for the following valves:

a) low-resistance valves before the radiators, closing valves at the bottom of the risers and at the connection to the heating system - the pressure gradient at the connection to the heating system is variable,

b) high-resistance valves before the radiators - the pressure gradient at the connection to the heating system is constant,

c) for a static hydraulic balance of the heating system - high-resistance valves with a pre-set, located before the radiators; bal-

Tab. 4 Effective uplift for the radiator on the top floor at a height of $20.5 \mathrm{~m}$ above the reference plane.

\begin{tabular}{|c|c|c|c|c|c|c|c|}
\hline $\boldsymbol{\theta}_{\mathrm{ae}}\left({ }^{\circ} \mathbf{C}\right)$ & $\boldsymbol{\theta}_{\mathrm{p}}\left({ }^{\circ} \mathbf{C}\right)$ & $\boldsymbol{\theta}_{\mathrm{v}}\left({ }^{\circ} \mathbf{C}\right)$ & $\boldsymbol{\Delta} \boldsymbol{\theta}\left({ }^{\circ} \mathbf{C}\right)$ & $\boldsymbol{\theta}_{\mathbf{s}}\left({ }^{\circ} \mathbf{C}\right)$ & $\boldsymbol{\varepsilon}(-)$ & $\mathbf{H}_{\mathrm{u}=\mathbf{1}}(\mathbf{P a})$ & $\mathbf{H}_{\mathrm{u}=\mathbf{0}, 5}(\mathbf{P a})$ \\
\hline-11 & 90.0 & 70.0 & 20.0 & 80.0 & 0.622 & 2,502 & 1,251 \\
\hline-4 & 77.2 & 61.8 & 15.5 & 69.5 & 0.567 & 1,766 & 883 \\
\hline 0 & 69.6 & 56.7 & 12.9 & 63.2 & 0.531 & 1,378 & 689 \\
\hline 4 & 61.7 & 51.3 & 10.3 & 56.5 & 0.491 & 1,019 & 510 \\
\hline 8 & 53.3 & 45.5 & 7.7 & 49.4 & 0.447 & 696 & 348 \\
\hline 13 & 39.4 & 35.5 & 3.9 & 37.5 & 0.360 & 280 & 140 \\
\hline
\end{tabular}

$\theta_{a e}$-temperature of the outside air $\left({ }^{\circ} \mathrm{C}\right), \theta_{p}$-temperature of the heating medium supplied $\left({ }^{\circ} \mathrm{C}\right) \theta_{v}$-temperature of the return heating medium $\left({ }^{\circ} \mathrm{C}\right), \Delta \theta$-difference between the supply and return temperature of the heating medium $\left({ }^{\circ} \mathrm{C}\right), \theta_{s}^{v}-$ mean temperature of the heating medium $\left({ }^{\circ} \mathrm{C}\right), \varepsilon$ - coefficient expressing change in the density of the heating medium (-), $H_{u=1}-$ effective uplift at the value of $u=1.0(P a), H_{u=0.5}-$ effective uplift at the value of $u=0.5(\mathrm{~Pa})$. 
ancing valves with a pre-set, located at the bottom of the risers; a pressure difference controller, located at the connection to the heating system - the pressure gradient at the connection to the heating system is constant (the heating system applied in the refurbished building),

d) for a dynamic hydraulic balance of the heating system high-resistance valves with a pre-set and a temperature controller, located before the radiators; balancing valves and pressure difference controllers, located at the bottom of the risers and at the connection to the heating system - the vertical piping was evaluated (heating system applied in the building in the original condition).

\section{a) Heating system with low-resistance valves before the radiators}

Inputs to the analysis:

- low-resistance valve with a pre-set, located on the supply pipe before the radiator,

- slope closing valves at the bottom of the risers,

- stop valve at the connection to the heating system,

- the pressure difference at the connection to the heating system is variable - the evaluation was done for the pressure differences of $4 \mathrm{kPa}$ and $12 \mathrm{kPa}$, respectively,

- the pressure loss of the pipe network is $\Delta \mathrm{p}_{\mathrm{p}}=4,332 \mathrm{~Pa}$ at a $100 \%$ volume flow rate, $\Delta \mathrm{p}_{\mathrm{p}}=2,132 \mathrm{~Pa}$ at a $70 \%$ volume flow rate, $\Delta \mathrm{p}_{\mathrm{p}}=1,163 \mathrm{~Pa}$ at a $50 \%$ volume flow rate.

\section{b) Heating system with high-resistance valves before the radiators}

Inputs to the analysis:

- high-resistance valve with a pre-set, located in the supply pipe before the radiator,

- slope closing valves at the bottom of the risers,

- the pressure difference controller at the connection to the heating system - the pressure gradient at the connection to the heating system is kept constant at $10 \mathrm{kPa}$,

- the pressure loss of the pipe network is $\Delta \mathrm{p}_{\mathrm{p}}=4,332 \mathrm{~Pa}$ at a $100 \%$ volume flow rate,

$\Delta \mathrm{p}_{\mathrm{p}}=2,132 \mathrm{~Pa}$ at a $70 \%$ volume flow rate, $\Delta \mathrm{p}_{\mathrm{p}}=1,163 \mathrm{~Pa}$ at a $50 \%$ volume flow rate.

\section{c) Heating system equipped with static valves}

Inputs to the analysis:

- high-resistance valve with a pre-set, located in the supply pipe before the radiator,

- balancing valves at the bottom of the risers - valves of a static character,

- the pressure difference controller at the connection to the heating system - the pressure difference at the connection to the heating system is kept constant, $13 \mathrm{kPa}$,

- the pressure loss of the pipe network is $\Delta \mathrm{p}_{\mathrm{p}}=7,332 \mathrm{~Pa}$ at a $100 \%$ volume flow rate, $\Delta \mathrm{p}_{\mathrm{p}}=3,337 \mathrm{~Pa}$ at a $70 \%$ volume flow rate, $\Delta \mathrm{p}_{\mathrm{p}}=1,763 \mathrm{~Pa}$ at a $50 \%$ volume flow rate.

\section{d) Heating system equipped with dynamic valves}

Inputs to the analysis:

- calculation of the pressure conditions referring to the bottom of the risers (in cases a, b and c the calculations refer to the point of connection to the heating system.

- high-resistance valve with a pre-set located in the supply pipe before the radiator,

- balancing valve combined with a pressure difference controller located at the bottom of the risers - pressure gradient at the bottom of the risers is kept constant at $7 \mathrm{kPa}$,

- the pressure loss of the pipe network is $\Delta \mathrm{p}_{\mathrm{p}}=1,656 \mathrm{~Pa}$ at a $100 \%$ volume flow rate, $\Delta \mathrm{p}_{\mathrm{p}}=798 \mathrm{~Pa}$ at a $70 \%$ volume flow rate, $\Delta \mathrm{p}_{\mathrm{p}}=459 \mathrm{~Pa}$ at a $50 \%$ volume flow rate.

The pressure conditions on the radiators in the heating system with valves before the radiators, for the four cases investigated in this study, are in Figs. 6 and 7.

From the graph in Fig. 7 it can be seen that before the refurbishment at a $100 \%$ volume flow rate of the heating medium, the calculation pressure loss of the valve and the calculation pressure before the valve are virtually the same (columns 1 and 2). However, in reality the pressure before the valve relative to the pressure loss of the heating system is much higher (column 3 ) due to the high effective uplift. Column 4 shows that the destabilisation of the pressure gradient at the connection to the heating system causes an increase of the pressure before the radiator valve to an extent that the valve cannot cope with,

Tab. 5 Pressure conditions on the radiator in the heating system with low-resistance valves before the radiators.

\begin{tabular}{|c|c|c|c|c|c|c|c|c|c|c|c|c|}
\hline \multirow{2}{*}{$\begin{array}{c}\boldsymbol{\theta}_{\text {ae }} \\
\left({ }^{\circ} \mathbf{C}\right)\end{array}$} & \multicolumn{4}{|c|}{$100 \%$ volume flow rate } & \multicolumn{4}{|c|}{$70 \%$ volume flow rate } & \multicolumn{4}{|c|}{$50 \%$ volume flow rate } \\
\hline & $\begin{array}{c}\mathbf{p}_{\mathrm{v0}} \\
(\mathrm{Pa})\end{array}$ & $\begin{array}{c}\mathbf{p}_{\text {dispv0 }} \\
\text { (Pa) }\end{array}$ & $\begin{array}{c}\mathbf{P}_{\text {dispv-4 }} \\
(\mathbf{P a})\end{array}$ & $\begin{array}{c}\mathbf{p}_{\text {dispV-12 }} \\
(\mathrm{Pa})\end{array}$ & $\begin{array}{c}\mathbf{p}_{\mathrm{v0}} \\
(\mathbf{P a})\end{array}$ & $\begin{array}{c}\mathbf{p}_{\text {dispv0 }} \\
\text { (Pa) }\end{array}$ & $\begin{array}{c}\mathbf{p}_{\text {dispv-4 }} \\
(\mathbf{P a})\end{array}$ & $\begin{array}{c}\mathbf{p}_{\text {dispV-12 }} \\
(\mathrm{Pa})\end{array}$ & $\begin{array}{c}\mathbf{p}_{\mathrm{v0}} \\
(\mathrm{Pa})\end{array}$ & $\begin{array}{c}\mathbf{p}_{\text {dispvo }} \\
\text { (Pa) }\end{array}$ & $\begin{array}{c}\mathbf{p}_{\text {dispv-4 }} \\
(\mathbf{P a})\end{array}$ & $\begin{array}{c}\mathbf{p}_{\text {dispV-12 }} \\
\text { (Pa) }\end{array}$ \\
\hline-11 & 500 & 919 & 2,170 & 10,170 & 300 & 3,119 & 4,370 & 12,370 & 180 & 4,088 & 5,339 & 13,339 \\
\hline-8 & 500 & 919 & 1,833 & 9,833 & 300 & 3,119 & 4,033 & 12,033 & 180 & 4,088 & 5,002 & 13,002 \\
\hline-4 & 500 & 919 & 1,434 & 9,434 & 300 & 3,119 & 3,634 & 11,634 & 180 & 4,088 & 4,603 & 12,603 \\
\hline 0 & 500 & 919 & 1,046 & 9,046 & 300 & 3,119 & 3,246 & 11,246 & 180 & 4,088 & 4,215 & 12,215 \\
\hline 4 & 500 & 919 & 687 & 8,687 & 300 & 3,119 & 2,887 & 10,887 & 180 & 4,088 & 3,856 & 11,856 \\
\hline 8 & 500 & 919 & 364 & 8,364 & 300 & 3,119 & 2,564 & 10,564 & 180 & 4,088 & 3,533 & 11,533 \\
\hline 13 & 500 & 919 & 75 & 8,075 & 300 & 3,119 & 2,275 & 10,275 & 180 & 4,088 & 3,244 & 11,244 \\
\hline
\end{tabular}

$\theta_{a e}$ - outside air temperature $\left({ }^{\circ} \mathrm{C}\right), p_{V 0}-$ calculation pressure loss of the valve $(\mathrm{Pa}), p_{\text {disp } V 0}-$ calculation pressure gradient before the radiator valve (4 $\mathrm{kPa}$ at the connection to the heating system) (Pa), $p_{\text {disp }-4}$-actual pressure gradient before the valve (4 $\mathrm{kPa}$ at the connection to the heating system) ( $\mathrm{Pa}$ ), $p_{\text {dispV-12 }}$ - actual pressure gradient before the valve (12 $\mathrm{kPa}$ at the connection to the heating system) (Pa). 
Tab. 6 Pressure conditions on the radiator in the heating system with high-resistance valves before the radiators.

\begin{tabular}{|c|c|c|c|c|c|c|c|c|c|}
\hline \multirow{2}{*}{$\begin{array}{c}\boldsymbol{\theta}_{\mathrm{ae}} \\
\left({ }^{\circ} \mathbf{C}\right)\end{array}$} & \multicolumn{3}{|c|}{$100 \%$ volume flow rate } & \multicolumn{3}{|c|}{$70 \%$ volume flow rate } & \multicolumn{3}{|c|}{$50 \%$ volume flow rate } \\
\hline & $\begin{array}{l}\mathbf{P}_{\mathrm{V0}-\mathrm{P}} \\
(\mathrm{Pa})\end{array}$ & $\begin{array}{c}\mathbf{p}_{\text {dispV0-P }} \\
(\mathbf{P a})\end{array}$ & $\begin{array}{c}\mathbf{p}_{\text {dispV-P }} \\
(\mathbf{P a})\end{array}$ & $\begin{array}{l}\mathbf{P}_{\mathrm{v} 0-\mathrm{P}} \\
(\mathrm{Pa})\end{array}$ & $\begin{array}{c}\mathbf{p}_{\text {dispv0-P }} \\
(\mathbf{P a})\end{array}$ & $\begin{array}{l}\mathbf{p}_{\mathrm{v} 0-\mathrm{N}} \\
(\mathrm{Pa})\end{array}$ & $\begin{array}{l}\mathbf{p}_{\mathrm{V0}-\mathrm{P}} \\
(\mathrm{Pa})\end{array}$ & $\begin{array}{c}\mathbf{P}_{\text {dispv0-P }} \\
(\mathbf{P a})\end{array}$ & $\begin{array}{l}\mathbf{p}_{\mathrm{v} 0-\mathrm{N}} \\
(\mathrm{Pa})\end{array}$ \\
\hline-11 & 6,000 & 6,919 & 8,170 & 2,800 & 10,370 & 7,800 & 1,700 & 11,339 & 9,000 \\
\hline-8 & 6,000 & 6,919 & 7,833 & 2,800 & 10,033 & 7,800 & 1,700 & 11,002 & 9,000 \\
\hline-4 & 6,000 & 6,919 & 7,434 & 2,800 & 9,634 & 7,800 & 1,700 & 10,603 & 9,000 \\
\hline 0 & 6,000 & 6,919 & 7,046 & 2,800 & 9,246 & 7,800 & 1,700 & 10,215 & 9,000 \\
\hline 4 & 6,000 & 6,919 & 6,687 & 2,800 & 8,887 & 7,800 & 1,700 & 9,856 & 9,000 \\
\hline 8 & 6,000 & 6,919 & 6,364 & 2,800 & 8,564 & 7,800 & 1,700 & 9,533 & 9,000 \\
\hline 13 & 6,000 & 6,919 & 6,075 & 2,800 & 8,275 & 7,800 & 1,700 & 9,244 & 9,000 \\
\hline
\end{tabular}

$\theta_{a e}$-outside air temperature $\left({ }^{\circ} \mathrm{C}\right), p_{V 0}$-calculation pressure loss of the valve $(\mathrm{Pa}), \mathrm{p}_{\text {disp } v}$ - calculation pressure gradient before the valve (Pa), $p_{\text {disp V0 }}$-actual pressure gradient before the valve $(\mathrm{Pa}), P$-original valve, $N$-valve with a new setting.

Tab. 7 Pressure conditions on the radiator in the heating system with static valves.

\begin{tabular}{|c|c|c|c|c|c|c|c|c|c|}
\hline \multirow{2}{*}{$\begin{array}{c}\boldsymbol{\theta}_{\mathrm{ae}} \\
\left({ }^{\circ} \mathbf{C}\right)\end{array}$} & \multicolumn{3}{|c|}{$100 \%$ volume flow rate } & \multicolumn{3}{|c|}{$70 \%$ volume flow rate } & \multicolumn{3}{|c|}{$50 \%$ volume flow rate } \\
\hline & $\begin{array}{l}\mathbf{p}_{\mathrm{V} 0-\mathrm{p}} \\
(\mathrm{Pa})\end{array}$ & $\begin{array}{c}\mathbf{p}_{\text {dispv0-P }} \\
(\mathrm{Pa})\end{array}$ & $\begin{array}{c}\mathbf{p}_{\text {dispV-P }} \\
(\mathbf{P a})\end{array}$ & $\begin{array}{l}\mathbf{p}_{\mathbf{v 0 - p}} \\
(\mathbf{P a}) \\
\end{array}$ & $\begin{array}{c}\mathbf{p}_{\text {dispv0-P }} \\
(\mathbf{P a})\end{array}$ & $\begin{array}{r}\mathbf{p}_{\mathrm{V} 0-\mathrm{N}} \\
(\mathrm{Pa})\end{array}$ & $\begin{array}{l}\mathbf{p}_{\mathrm{V} 0-\mathrm{P}} \\
(\mathrm{Pa})\end{array}$ & $\begin{array}{c}\mathbf{p}_{\text {dispv0-P }} \\
(\mathbf{P a})\end{array}$ & $\begin{array}{l}\mathbf{p}_{\mathrm{v0-N}} \\
(\mathrm{Pa}) \\
\end{array}$ \\
\hline-11 & 6,000 & 6,919 & 8,170 & 2,800 & 12,165 & 10,000 & 1,700 & 13,739 & 11,000 \\
\hline-8 & 6,000 & 6,919 & 7,833 & 2,800 & 11,828 & 10,000 & 1,700 & 13,402 & 11,000 \\
\hline-4 & 6,000 & 6,919 & 7,434 & 2,800 & 11,429 & 10,000 & 1,700 & 13,003 & 11,000 \\
\hline 0 & 6,000 & 6,919 & 7,046 & 2,800 & 11,041 & 10,000 & 1,700 & 12,615 & 11,000 \\
\hline 4 & 6,000 & 6,919 & 6,687 & 2,800 & 10,682 & 10,000 & 1,700 & 12,256 & 11,000 \\
\hline 8 & 6,000 & 6,919 & 6,364 & 2,800 & 10,359 & 10,000 & 1,700 & 11,933 & 11,000 \\
\hline 13 & 6,000 & 6,919 & 6,075 & 2,800 & 10,070 & 10,000 & 1,700 & 11,644 & 11,000 \\
\hline
\end{tabular}

$\theta_{a e}$-outside air temperature $\left({ }^{\circ} \mathrm{C}\right), p_{V 0}-$ calculation pressure loss of the valve $(\mathrm{Pa}), p_{\text {disp } v}-$ calculation pressure gradient before the valve $(\mathrm{Pa})$, $p_{\text {disp }}-$ actual pressure gradient before the valve $(\mathrm{Pa}), P$ - original valve, $N$-valve with a new setting.

Tab. 8 Pressure conditions on the radiator in the heating system with dynamic valves.

\begin{tabular}{|c|c|c|c|c|c|c|c|c|c|}
\hline \multirow{2}{*}{$\begin{array}{c}\boldsymbol{\theta}_{\mathrm{ae}} \\
\left({ }^{\circ} \mathbf{C}\right)\end{array}$} & \multicolumn{3}{|c|}{$100 \%$ volume flow rate } & \multicolumn{3}{|c|}{$70 \%$ volume flow rate } & \multicolumn{3}{|c|}{$50 \%$ volume flow rate } \\
\hline & $\begin{array}{l}\mathbf{p}_{\mathrm{V} 0-\mathrm{p}} \\
(\mathrm{Pa})\end{array}$ & $\begin{array}{c}\mathbf{p}_{\text {dispV0-P }} \\
(\mathrm{Pa})\end{array}$ & $\begin{array}{c}\mathbf{p}_{\text {dispV-P }} \\
(\mathbf{P a})\end{array}$ & $\begin{array}{l}\mathbf{p}_{\mathrm{V} 0-\mathrm{P}} \\
(\mathrm{Pa})\end{array}$ & $\begin{array}{c}\mathbf{p}_{\text {dispv0-P }} \\
(\mathbf{P a})\end{array}$ & $\begin{array}{l}\mathbf{p}_{\mathrm{V} 0-\mathrm{N}} \\
(\mathrm{Pa})\end{array}$ & $\begin{array}{l}\mathbf{p}_{\mathrm{V0}-\mathrm{P}} \\
(\mathrm{Pa})\end{array}$ & $\begin{array}{c}\mathbf{p}_{\text {dispv0-P }} \\
(\mathbf{P a})\end{array}$ & $\begin{array}{l}\mathbf{p}_{\mathrm{v} 0-\mathrm{N}} \\
(\mathrm{Pa})\end{array}$ \\
\hline-11 & 6,000 & 6,595 & 7,846 & 2,800 & 8,704 & 6,000 & 1,700 & 9,043 & 6,000 \\
\hline-8 & 6,000 & 6,595 & 7,509 & 2,800 & 8,367 & 6,000 & 1,700 & 8,706 & 6,000 \\
\hline-4 & 6,000 & 6,595 & 7,110 & 2,800 & 7,968 & 6,000 & 1,700 & 8,307 & 6,000 \\
\hline 0 & 6,000 & 6,595 & 6,722 & 2,800 & 7,580 & 6,000 & 1,700 & 7,919 & 6,000 \\
\hline 4 & 6,000 & 6,595 & 6,363 & 2,800 & 7,221 & 6,000 & 1,700 & 7,560 & 6,000 \\
\hline 8 & 6,000 & 6,595 & 6,040 & 2,800 & 6,898 & 6,000 & 1,700 & 7,237 & 6,000 \\
\hline 13 & 6,000 & 6,595 & 5,751 & 2,800 & 6,609 & 6,000 & 1,700 & 6,948 & 6,000 \\
\hline
\end{tabular}

$\theta_{a e}$-outside air temperature $\left({ }^{\circ} \mathrm{C}\right), p_{V 0}-$ calculation pressure loss of the valve $(\mathrm{Pa}), \mathrm{p}_{\text {disp } V 0}-$ calculation pressure gradient before the valve $(\mathrm{Pa})$, $p_{\text {disp }}$-actual pressure gradient before the valve $(\mathrm{Pa}), P$ - original valve, $N$-valve with a new setting. 


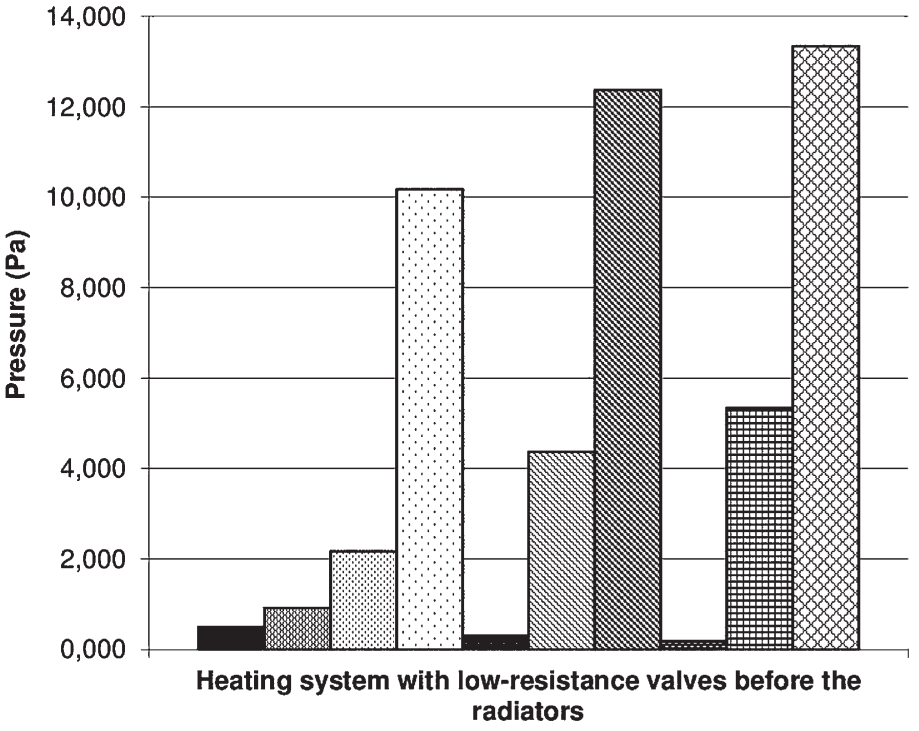

Fig. 7 Pressure conditions on the radiator in the heating system with low-resistance valves before the radiators. $50 \%$ volume flow rate
Dressure loss of the valve at a $100 \%$ volume flow rate

calculation pressure before the valve at a $100 \%$ volume flow rate

Tactual pressure before the valve, pressure at the connection to the heating system set to $4 \mathrm{kPa}$ at a $100 \%$ volume flow rate

घactual pressure before the valve, pressure at the connection to the heating system set to $12 \mathrm{kPa}$ at a $100 \%$ volume flow rate

mpressure loss of the valve at a $70 \%$ volume flow rate

Eactual pressure before the valve, pressure at the connection to the heating system set to of $4 \mathrm{kPa}$ at a $70 \%$ volume flow rate

\$actual pressure before the valve, pressure at the connection to the heating system set to $12 \mathrm{kPa}$ at a $70 \%$ volume flow rate

国pressure loss of the valve at a $50 \%$ volume flow rate

Gactual pressure before the valve, pressure at the connection to the heating system set to $4 \mathrm{kPa}$ at a $50 \%$ volume flow rate

$\square$ actual pressure before the valve, pressure at the connection to the heating system set to $12 \mathrm{kPa}$ at a

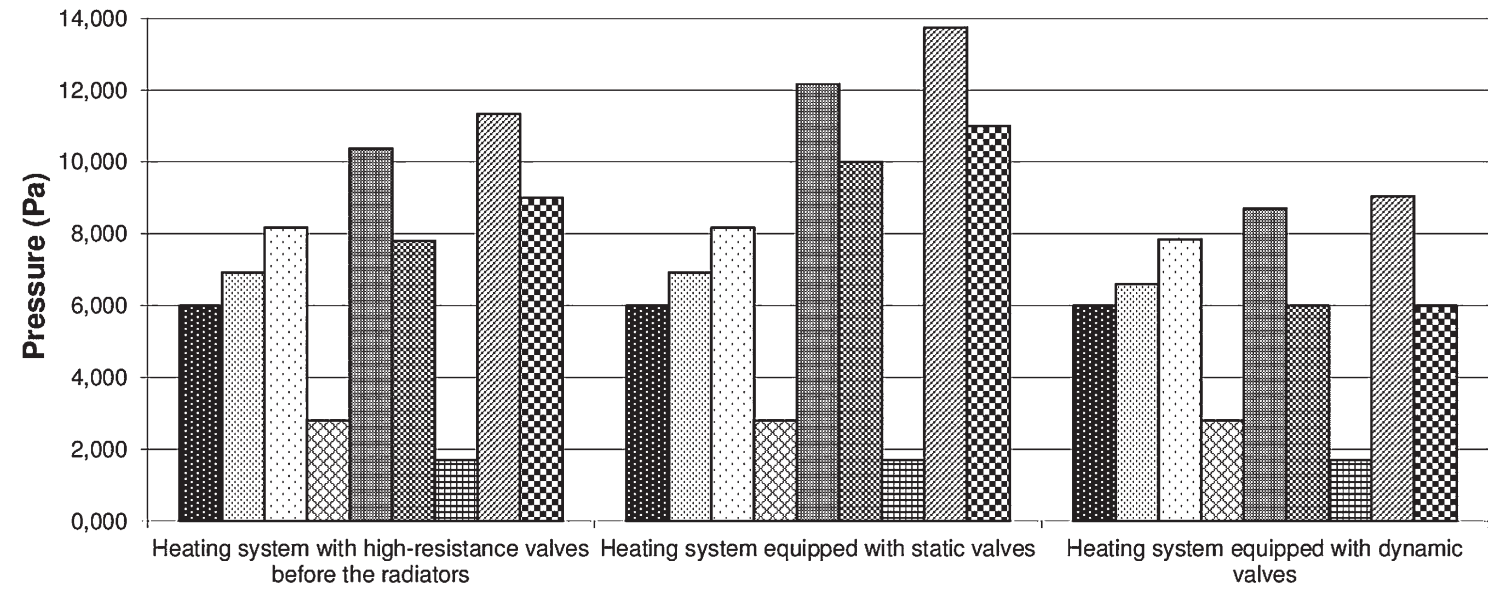

Valves applied in the heating system

- pressure loss of the valve at a $100 \%$ volume flow rate

Dactual pressure before the valve at a $100 \%$ volume flow rate

⿴囗十 actual pressure before the valve at a $70 \%$ volume flow rate

Tpressure loss of the original valve at a $50 \%$ volume flow rate ⿴calculated pressure before the valve at a $100 \%$ volume flow rate

هpressure loss of the original valve at a $70 \%$ volume flow rate

Bpressure loss of the valve with the new setup at a $70 \%$ volume flow rate Dactual pressure before the valve at a $50 \%$ volume flow rate

Dpressure loss of the valve with the new setup at a $50 \%$ volume flow rate

Fig. 8 Pressure conditions on the radiator.

resulting in a significant lack of balance of the system. The situation is further exacerbated by decreasing the volume flow rate as a consequence of the thermal insulation of the building, when the difference between the pressure loss on the valve (columns 5 and 8 ) and the pressure before the valve (columns 6,7 and 9,10) increases significantly. For this reason, low-resistance valves are not more suitable for current heating systems. Moreover, assuring a constant pressure at the connection to the heating system is necessary.

In Fig. 8 it can be seen that when using high-resistance valves, the effect of an effective uplift on the pressure conditions before the valve is negligible (columns 2 and 3). When the volume flow rate is decreased, the pressure loss of the heating network, as well as the pressure loss of the valve before the radiator (columns 4 and 7), decreases, and the system becomes unbalanced from the point of view of the hydraulic conditions (columns 5 and 8 ). The difference between the pressure loss of the valve before the radiator and the pressure before the valve increases even more after the installation of balancing valves (static valves - they work in a way similar to the pipe network) at the bottom of the risers (columns 5 and 8 - solution 2). Therefore, after the insulation of the building envelope and the subsequent decrease of the volume flow rate, it is necessary to change the pre-set of 
the valve before the radiator (if the valve construction permits that) or to replace the valve with a more suitable one (columns 6 and 9). If the pressure before the valve is so high that the valve is not able to cope, it is necessary to split the heating system into two separate hydraulic sections (solution 3 ) and install a balancing valve in combination with a pressure difference controller at the bottom of the risers.

\section{THE EFFECT OF REFURBISHMENT ON THE THERMO-HYDRAULIC STABILITY OF THE HEATING SYSTEM}

From the abovementioned tables and figures, it can be seen that the variations in the volume flow rate through the heating system as a result of the thermal insulation of the envelope affect the pressure conditions in the heating system and, thereby, the thermo-hydraulic stability of the heating system. The extent of this effect can be quantified by the degree of hydraulic stability X, expressed through the volume flow rate or through the pressure difference (pressure gradient) (Andreas at al., 1985; Bašta, 2003; Petitjean, 1998):

$$
\begin{gathered}
X=\frac{M}{M_{0}} \\
X=\left(\frac{\Delta p}{\Delta p_{0}}\right)^{0,5}
\end{gathered}
$$

$M$-immediate volume flow rate of the heating medium through a section of the heating system $(\mathrm{kg} / \mathrm{s})$,

$M_{0}$ - calculation of the volume flow rate of the heating medium through a section of the heating system $(\mathrm{kg} / \mathrm{s})$,

$\Delta p$-immediate pressure difference referring to the corresponding section of the distribution network $(\mathrm{Pa})$,

$\Delta p_{0}$ - calculation of the pressure difference referring to the corresponding section of the distribution network $(\mathrm{Pa})$.

The degree of hydraulic stability compares the actual immediate condition with the calculated condition. A degree of hydraulic stability of at least 0.7 is recommended for two-pipe heating systems (Bašta, 2003; Pekarovič at al., 1994).

By decreasing the volume flow rate of the heating medium as a consequence of the thermal insulation of the apartment building to a value of $70 \%$ or $50 \%$ of the original calculated volume flow rate, the degree of hydraulic stability, calculated in accordance with equation (1), will be 0.7 and 0.5 , respectively. In the former case, the boundary value is still reached, but in the latter case the degree of hydraulic stability indicates an unstable heating system.
The formulation of the degree of hydraulic stability through volume flow rates in accordance with equation (1) does not consider the way in which the heating system is balanced. On the other hand, the degree of hydraulic stability expressed through pressure gradients in accordance with equation (2) also takes into account the effect of the heating system and its components. Therefore, it is more efficient to calculate the degree of hydraulic stability based on equation (2). The degree of hydraulic stability, which is calculated based on the pressure gradients in the heating system for different types of valves in the system before and after refurbishment of the heating system (replacement of the valves before the radiator), is listed in Tab. 9 .

From Tab. 9 it can be seen that by decreasing the volume flow rate of the heating medium as a consequence of the thermal insulation of the building, without any intervention in the heating system, the required degree of hydraulic stability of $X \geq 0.7$ is achieved only in the case with high-resistance valves (case b). After the refurbishment of the heating system by replacing the low-resistance valves with high-resistance valves and by changing the setting of the pressure gradients of the existing high-resistance valves or eventually by the replacement of the valves, the degree of hydraulic stability of the existing heating system increases above 0.9 . Increasing the degree of hydraulic stability has a positive effect on the uniform distribution of the volume flow rates among the radiators.

\section{RECOMMENDATIONS ON REFURBISHING HEATING SYSTEMS WITH RESPECT TO THE THERMO-HYDRAULIC STABILITY OF THE SYSTEM}

After the refurbishment of the apartment building, the requirements for the heat flow to the heating system connected to the district heating system changed. Based on the present study, the following recommendations can be given in order to assure the thermo-hydraulic stability:

- After a complex refurbishment of an envelope, the volume flow rate of the heating medium changes to $50 \%$.

- The temperature of the heating medium in a refurbished heating system remains unchanged.

- The original radiators remain; a change of radiators should only be considered on the floor above the underground floor and the top floor.

- A pressure difference controller should be installed at the connection to the heating system.

- High-resistance valves with thermostatic heads and the possibility of a pre-set (fluent or with only a small distance between

Tab. 9 Degree of the hydraulic stability of the heating system before and after renovation.

\begin{tabular}{|l|c|c|c|c|}
\hline \multirow{2}{*}{ Valves in the heating system } & \multicolumn{3}{|c|}{$\begin{array}{c}\text { Degree of hydraulic stability } X(\%) \\
\text { Variation of the volume flow rate }\end{array}$} \\
\cline { 2 - 5 } & \multicolumn{3}{|c|}{ Original valves } & Valves with new setting \\
\cline { 2 - 5 } & $\mathbf{7 0 \%}$ & $\mathbf{5 0 \%}$ & $\mathbf{7 0} \%$ & $\mathbf{5 0} \%$ \\
\hline a1) system with low-resistance valves before radiators - pressure gradient of 4 kPa & 0.78 & 0.58 & - & - \\
\hline a2) system with low-resistance valves before radiators - pressure gradient of $12 \mathrm{kPa}$ & 0.45 & 0.33 & - & - \\
\hline b) system with high-resistance valves before radiators & 0.70 & 0.50 & 0.99 & 0.997 \\
\hline c) system with static hydraulic balance & 0.69 & 0.52 & 0.997 & 0.99 \\
\hline d) system with dynamic hydraulic balance & 0.55 & 0.48 & 0.99 & 0.97 \\
\hline
\end{tabular}


the pre-set values) should be installed before the radiators. The minimum pressure loss of the valve is twice the maximum effective uplift; the maximum pressure loss is limited by the acoustic pressure level of the valve, as given by the manufacturer.

- After the refurbishment of a heating system, it is always necessary to perform calculations of the hydraulic conditions - the balancing of the heating system. The effective uplift should not be taken into account in the calculations.

- The application of balancing valves at the bottom of the risers is only possible in combination with a pressure difference controller.

- The pressure loss of the balancing valve should be low and is affected by any pressure losses of the circuit. The minimum preset value of the balancing valve is given by the manufacturer, and as a rule it is represented by the second curve from the left.

- Only balancing valves suited for the insertion of measuring probes in order to allow an investigation of the physical parameters in a heating system should be installed in a heating system.

- Only pressure difference controllers suited for an interconnection with the balancing valve and for the insertion of measuring probes permitting the measurement of the physical parameters in the heating system should be installed in a heating system.

\section{CONCLUSION}

In the present contribution, thermal and hydraulic conditions are analysed for the heating systems of two apartment buildings, one being in its original condition and the other after the refurbishment of the building constructions. The refurbishment should have a significant effect on the thermal losses of the structure and subsequently on the hydraulic conditions and hydraulic stability of the heating system.

The study was aimed at the:

a) analysis and synthesis of the results obtained by the author's own mathematical calculation tool, created using Microsoft Ex$\mathrm{cel}^{\mathrm{O}}$, to calculate thermal losses, pressure conditions in a heating system and the hydraulic stability of a heating system, b) correction of the typically recommended ratio of the effective uplift in a heating system after the refurbishment of an apartment building; the effective uplift should not be taken into account in the calculations,

c) methodology of the calculations and the evaluation and design of heating systems, with respect to the application of control valves after the refurbishment of the envelope,

d) optimization of the physical parameters of heating systems in the process of refurbishment,

e) optimization of the degree of the hydraulic stability of heating systems in apartment buildings after refurbishment - the correction of the degree of the hydraulic stability value after refurbishment to $X \geq 0.85$,

f) the extraction of an algorithm for the design of control valves after the refurbishment of an apartment building.

Based on the analysis of the effect of the changes in the thermal characteristics of the building envelope on the thermal losses of the building and, subsequently, the effect of the decrease in thermal losses on the hydraulic conditions in the heating system from the point of view of the thermo-hydraulic stability, it can be concluded that the refurbishment of the envelope constructions of a building has to be followed by a refurbishment of the heating system. After the refurbishment, it is necessary to replace the low-resistance valves by high-resistance valves. The installation of the high-resistance valves results in an increased degree of hydraulic stability. A constant pressure gradient has to be set at the connection to the heating system by installing a pressure difference controller in combination with a balancing valve. By following these recommendations, an energy saving of 40 to $50 \%$ can be achieved.

\section{Acknowledgements}

The present research was funded by the VEGA 1/1052/11 project. 


\section{REFERENCES}

Andreas, U. - Winter, A. - Wolff, D. (1985) Regelung Heiztechnischer Anlagen (Devices for the control of heating systems), VDIVerlag, Düsseldorf, 1985. ISBN 3184006905.

Bašta, J. (2003) Hydraulika a řizení otopných soustav. (Hydraulics and control of heating systems) ČVUT, Prague, 2003. ISBN 8001-02808-9.

Burkhardt, W. - Kraus, R. (2006) Projektierung von Warmwasserheizungen. (Design of water-based heating systems) 7. Auflage. Oldenburg Industrieverlag, Munich, 2006.

Pekarovič, J. K. Petráš, D. - Lulkovičová, O. - Takács, J. (1994) Vykurovanie. II. diel. (Space heating, Part II.) SVŠT, Bratislava, ISBN 85-230-94.

Petitjean, R. (1997) Total hydronic balancing. Responstryck Boras.

Roos, H. (2002) Hydraulik der Wasserheizung. (Hydraulics of water-based heating systems) 5. Auflage. Oldenburg Verlag, München, ISBN 3-486-26521-6.

Dahlsveen, T. - Petrášs, D. (2003) Energetický audit budov. (Energy audit of buildings) Jaga, Bratislava, ISBN 80-88905-86-9.

Chmúrny, I. (2003) Tepelná ochrana budov. (Thermal protection of buildings) Jaga, Bratislava, ISBN 80-88905-27-3.
Petitjean, R. (1998) Stabilizace diferenčniho tlaku ve vytápěcích soustavách a klimatizačních zařizení. Manuál č. 4 pro navrhováni a vyvažováni vytápěcich soustav a klimatizačnich zařizení. (The stability of the differential pressure in heating and air conditioning systems) TA Hydronics, Prague.

Šulcová, D. (1999) Otopové křivky. (Heating curves) Příloha časopisu Topin. Technické vydavatelství, Prague.

Kotrbatý, M. - Hojer, O. - Kovářová, Z. (2009) Hospodaření teplem v průmyslu. Nejlevnějši energie je energie ušetřena. (Thermal management in industry. The cheapest energy is saved energy) ČSTZ, Prague, ISBN 978-80-86028-41-5.

STN EN 12831 (2004) Vykurovacie systémy v budovách. Metóda výpočtu projektovaného tepelného prikonu. (Heating systems in buildings. Method for calculation of the design heat load).

STN 730540 (1964) Tepelně technické vlastnosti stavebních konstrukci a budov. Názvosloví. Požadavky a kritéria. (Thermal insulation characteristics of building constructions and buildings. Terminology. Requirements and criteria).

STN 73 0540-2 (2012) Tepelná ochrana budov. Tepelno-technické vlastnosti stavebných konštrukcii a budov. Čast’ 2: Funkčné požiadavky. (Thermal protection of buildings. Thermal insulation characteristics of building constructions and buildings. Part 2: Functional requirements). 